\title{
CUCUMBIS CARNAVALESCOS: ÁFRICAS, CARNAVAL E ABOLIÇÃO (RIO DE JANEIRO, DÉCADA DE 1880)*
}

Eric Brasil ${ }^{* *}$

$\mathrm{O}$ toque do agogô, alto e agudo, chegava primeiro à esquina da Rua Primeiro de Março com a Rua do Ouvidor. Logo em seguida, o som dos chocalhos, tamborins e adufos atraía os ouvidos e os olhares daqueles que se apertavam no chão e nas sacadas. No mesmo instante em que os gritos e cânticos graves e retumbantes inundavam a Rua do Ouvidor, era possível distinguir as primeiras plumas de cocares e pontas de lanças dobrando a esquina.

O préstito de aproximadamente duas dezenas de pessoas avançou pela estreita rua, dançando e cantando sem parar. Eram homens e mulheres negros vestidos de "índios", com penas, tacapes, lanças, escudos, carregando cobras e lagartos (alguns vivos). Uma mulher ricamente adornada, com manto e cetro, era carregada num andor. Era a Rainha, e ao seu lado vinha o Rei. Seus súditos tocavam instrumentos pouco comuns para os habituais frequentadores da Rua do Ouvidor. Cantavam numa

\footnotetext{
* Esse artigo é uma versão do capítulo IV de "Carnavais da abolição: diabos e cucumbis no Rio de Janeiro (1879-1888)" (Dissertação de Mestrado, Universidade Federal Fluminense, 2011), vencedora do Concurso Sílvio Romero de Monografias sobre Folclore e Cultura Popular, ano de 2011, do Instituto do Patrimônio Histórico e Artístico Nacional, por meio do Centro Nacional de Folclore e Cultura Popular (IPHAN/CNFCP).

** Doutorando pelo Programa de Pós-Graduação em História Social da Universidade Federal Fluminense.
} 
língua menos comum ainda. Mas era carnaval, sua corte estava passando, e uma frase entre tantas outras ficou clara para todos os presentes: "A África sempre foi livre", cantavam os membros do grupo chamado Cucumbis Africanos.

Esse episódio ocorreu na segunda-feira de carnaval do ano de 1888 e foi noticiado pelo Jornal do Comércio ${ }^{1}$ e é um bom exemplo de um fenômeno curioso, mas não inexplicável, que ganhou força na segunda metade da década de 1880 no carnaval carioca. Refiro-me à crescente aparição de grupos explicitamente associados a práticas africanas nos jornais do Rio de Janeiro, autointitulados Cucumbis. Não encontrei referências a esses grupos, enquanto associações carnavalescas, antes de 1884 nos três jornais pesquisados (Gazeta de Notícias, Gazeta da Tarde e Jornal do Comércio), nem na Revista Ilustrada. Entretanto, entre 1884 e 1888 , sua presença tornar-se-ia cada vez mais significativa - tanto quantitativa quanto qualitativamente — nas folhas diárias.

Obviamente, não estou afirmando que tais sociedades tenham surgido apenas em 1884; o que pretendo discutir é por que, justamente a partir desse momento, elas começam a ganhar espaço nos periódicos da Corte nos dias de carnaval. Este artigo pretende analisar também quais os significados dessa imagem africana produzida tanto pelos próprios membros desses grupos quanto pela imprensa, por memorialistas, folcloristas e viajantes. Acredito ser de grande importância considerarmos esses grupos em relação com todo o processo de desestruturação da escravidão, vivido tão intensamente na cidade do Rio de Janeiro na década de 1880. Para tanto, precisaremos ir mais distante, no tempo e no espaço: voltar até o período colonial em busca das congadas e outras festas semelhantes; atravessar o Atlântico em busca de referências históricas que nos ajudem a entender a força dessa prática que, mais de três décadas depois da extinção do tráfico, fez homens e mulheres saírem às ruas cantando, dançando e contando histórias de uma certa África.

1 Jornal do Comércio, 14 de fevereiro de 1888, Biblioteca Nacional, Seção de Periódicos.

274 Afro-Ásia, 49 (2014), 273-312 


\section{Memorialistas, folcloristas e viajantes sobre antigos Cucumbis}

Ao ler os jornais dos dias de carnaval da década de 1880, me deparei com uma pluralidade enorme de atores e práticas convivendo - não harmoniosamente - lado a lado nas estreitas ruas do Rio de Janeiro. O carnaval das ruas apresentava centenas de foliões fantasiados de Velhos, Dominós, Mortes, Chicards, Morcegos, além dos famigerados diabinhos encarnados, presença constante nas páginas diárias e frequentadores assíduos dos xadrezes da cidade. ${ }^{2}$ Também era comum o relato de grupos populares percorrendo dia e noite o centro e os arrabaldes da Corte. A grande maioria desses grupos era chamada de Zé-Pereira pelos jornalistas. $^{3}$

Contudo, mesmo para um observador bastante distante, como muitos jornalistas, alguns grupos pareciam se destacar na multidão de foliões. O maior espaço nas páginas dos jornais era dedicado aos préstitos das grandes sociedades carnavalescas e outras sociedades e grupos que almejavam chegar próximo da glória ostentada por Democráticos, Fenianos e Tenentes do Diabo. Sociedades como Estudantes de Salamanca, Progressistas da Cidade Nova, Piratas do Amor, Congresso dos Socialistas, Cavaleiros de São Potino, entre tantas outras, desfilavam anualmente, aumentando a concorrência das ruas nos dias de carnaval. ${ }^{4}$

A partir de 1884, porém, uma nova denominação aparece nos jornais pesquisados: são os Cucumbis, apresentados simploriamente

2 Eric Brasil Nepomuceno, "Carnavais da abolição: diabos e cucumbis no Rio de Janeiro (18791888)" (Dissertação de Mestrado, Universidade Federal Fluminense, 2011).

O Zé-Pereira correspondia, em finais do século XIX, a um termo bastante genérico com o qual os jornalistas definiam grupos de foliões populares que pulassem o carnaval atrás de uma banda de zabumbas e bumbos, empunhados por sujeitos vestidos de casacas esfarrapadas, que carregavam estandarte. Atrás de si atraíam muita gente e, como afirma Cunha, causaram um grande impacto no carnaval dos máscaras avulsos: “ [o Zé-Pereira] forneceu ritmo à dança dos velhos e princeses, atraiu para a dança os diabinhos e demais personagens que, isolados, já pareciam assustadores" e que nessa "presença coletiva" pareciam ainda mais perigosos e abomináveis aos olhos de jornalistas e autoridades. Maria Clementina Pereira Cunha "Vários Zés, um sobrenome: as muitas faces do senhor Pereira no carnaval carioca da virada do século", in Maria Clementina Pereira Cunha (org.), Carnavais e outras f[r]estas: ensaios de história social da cultura (Campinas: Ed. da Unicamp/CECULT, 2002), pp. 371-418.

4 Maria Clementina Pereira Cunha, Ecos da folia: uma história social do carnaval carioca entre 1880 e 1920, São Paulo: Companhia das Letras, 2001. 
como grupos carnavalescos compostos exclusivamente por homens e mulheres negros, que se vestem, cantam, dançam e narram histórias à moda africana. Assim como os Zé-Pereiras, os Cucumbis representam uma possibilidade de ação coletiva nos dias de carnaval, mas trazem consigo também formas de identidade diferenciada, na medida em que possuem critérios especiais na aceitação ou não de membros.

Portanto, precisamos nos aproximar o máximo possível dessa experiência coletiva e festiva empreendida por negros e negras no carnaval do Rio de Janeiro, sobretudo por ganhar visibilidade na imprensa justamente no auge da crise do escravismo. Para tanto, é preciso buscar os relatos sobre a presença de Cucumbis no Brasil para além da festa carnavalesca.

No dia 13 de fevereiro de 1888, uma segunda-feira de carnaval, a Gazeta de Notícias publicara um longo texto assinado por Mello Moraes Filho intitulado "Os Cucumbis". Esse artigo seria publicado com algumas modificações em sua obra Festas e tradições populares do Brasil, ${ }^{5}$ na edição de 1901. Não é por acaso que o artigo de Mello Moraes compõe a Gazeta de Notícias naquele ano. Suas explicações sobre os Cucumbis correspondem ao crescente impacto desses grupos nas ruas (ou pelo menos a sua maior visibilidade diante de certos jornalistas), disputando espaço com as demais sociedades e Zé-Pereiras. Explicita, também, a curiosidade e a necessidade, por parte da imprensa, de se compreender minimamente a presença daqueles sujeitos cada vez mais atuantes nos dias de Momo.

Como esse texto foi produzido justamente no ano de 1888 e por tão destacado intelectual (servindo de base para autores futuros), ele será utilizado como ponto de partida para nossa aproximação das descrições dos Cucumbis feitas por memorialistas e folcloristas.

Mello Moraes inicia o texto fazendo uma breve "história" dos Cucumbis. Para ele, o termo Cucumbi teria origem na Bahia, onde esses grupos, ainda no período colonial, eram compostos exclusivamente por "escravos d'África" que cantavam suas "cantigas bárbaras unicamente na

Mello Moraes Filho, Festas e tradições populares do Brasil, Rio de Janeiro: Ediouro, 1967, pp. 191-202. 
linguagem de suas terras natalícias". ${ }^{6}$ Afirma que "em todos os tempos, por ocasião do entrudo e das festas do Natal, ranchos deles encontravam-se em lugares múltiplos, indo dançar e cantar em casas determinadas, ou nos tablados construídos ao lado das igrejas e nas praças". Nas demais províncias do Brasil receberiam o nome de Congos.

No Rio, prossegue Mello Moraes, os Cucumbis existiram até a década de 1830, e eram parte de "préstitos fúnebres dos filhos dos reis africanos aqui falecidos". O autor aproveita o gancho dos cortejos fúnebres para relacionar os Cucumbis com as tristezas da escravidão africana no Brasil. Afirma ele que, após desembarcar dos navios negreiros, com saudades de sua terra,

A dança dos Cucumbis ressoou estrepitosa nas florestas, ao tinir das correntes dos cepos e dos gemidos nas senzalas, ao som do açoite nas surras da escada e do soluço da mãe escrava, a quem tiravam para sempre dos braços o filhinho nu e misérrimo.

Logo, o enredo desse "baleto" não poderia ser outro que não um que versasse sobre o passado africano. Mello Moraes o resume da seguinte forma:

Depois da refeição lauta do cucumbe, a comida que usavam os congos e munhambanas nos dias da circuncisão de seus filhos, uma partida de Congos põe-se a caminho, indo levar à rainha os novos vassalos que haviam passado por essa espécie de batismo selvagem.

$\mathrm{O}$ préstito, formado por príncipes e princesas augures e feiticeiros, intérpretes de dialetos estrangeiros e inúmero povo, levando entre alas festivas os mamêtos circuncidados com a lasca de taquara, é acometido por uma tribo inimiga, caindo flechado o filho do rei.

Ao aproximar-se o cortejo, recebendo a notícia do embaixador, ordena o soberano que venha à sua presença um afamado adivinho, o feiticeiro mais célebre de seu reino, impondo-lhe a ressurreição do príncipe morto. "Ou darás a vida a meu filho, diz ele, e terás em recompensa em tesouro de miçangas e a mais bela das mulheres para com ela passares muitas noites; ou não darás, e te mandarei degolar."

\footnotetext{
6 Moraes Filho, Festas e tradições. As citações seguintes são dessa mesma obra.
} 
E aos sortilégios do feiticeiro, o morto levanta-se, as danças não findam, ultimando a função ruidosa retirada, na qual os Cucumbis cantam o Bendito e diversas quadras populares.

Essa grande passeata, que, segundo ele, poderia levar horas, era composta por homens e mulheres vestidos de círculos de penas aos joelhos, cintura, braços e punhos, além de cocar de traseira vermelha,

[...] botinas de cordovão enfeitadas de fitas e galões, calça e camisa de meia cor de carne, e ao pescoço das mulheres e homens, miçangas, corais e colares de dentes, dando uma ou mais voltas. O Feiticeiro, o Rei e a Rainha ostentam vestimenta mais luxuosa e característica, porém no mesmo sentido.

O instrumental que acompanhava incessantemente o préstito era composto por canzás, xequerês, chocalhos, tamborins, adufos, agogôs, marimbas e pianos de cuia, e mantinham a "lealdade às tradições" africanas.

Assim sendo, para Mello Moraes Filho, os Cucumbis possuíam um caráter essencialmente africano, tanto nas suas canções quanto nas danças e instrumentos e, obviamente, nas pessoas que participavam dele.

A associação dos Cucumbis com os cortejos fúnebres de reis africanos feita por Mello Moraes pode ser melhor analisada se a compararmos com os relatos de Jean-Baptiste Debret sobre esses eventos nas primeiras décadas do século XIX.7

No terceiro volume de Viagem pitoresca e histórica ao Brasil, encontramos uma prancha intitulada Convoi funèbre dun fils de roi nègre ("Cortejo fúnebre de um filho de rei negro") 8 e uma breve descrição do mesmo. Segundo o artista francês, não é raro encontrar, entre a multidão

\footnotetext{
Debret chegou ao Rio de Janeiro em 12 de agosto de 1816, como membro da Missão Francesa convocada por dom João VI. Planejava ficar seis anos, mas acabou permanecendo por quinze. Apesar de ter sido um pintor "áulico", produzindo inúmeras obras sobre a família real e atos oficiais, Debret nos legou magníficas gravuras sobre índios, negros, aspectos do cotidiano e dos costumes da população brasileira, especificamente do Rio de Janeiro. "Debret", in Ronaldo Vainfas (org.), Dicionário do Brasil Imperial (1822-1889) (Rio de Janeiro: Objetiva, 2004), pp. 396-7; Jean Baptiste Debret, Viagem pitoresca e histórica ao Brasil, Belo Horizonte: Itatiaia; São Paulo: USP, 1989.

8 Debret, Viagem pitoresca.
} 
de escravos, alguns "grands dignitaires éthiopiens" ("grandes dignitários etíopes"), que os seus ex-vassalos os reconhecem, lhes prestam homenagens e buscam meios de juntar dinheiro para comprar sua liberdade. Quando morre ou, então, seu filho morre, seu corpo é exposto com vestuário africano, recebendo visita de seus súditos e de delegações de negros de outras nações (compostas por três dignitários: um diplomata, um porta-estandarte e um capitão de guarda). Uma multidão de negros se aglomera fora da casa que abriga o corpo. Em seu interior, os negros cantam acompanhados de seus "instrumentos nacionais", reforçados pelas palmas das mãos daqueles que os rodeiam.

Ao anoitecer, o cortejo sai às ruas. O mestre de cerimônias sai da casa e, "a grandes golpes de rotin [a tradução literal é "vime"; aparentemente se refere a um pequeno pedaço de madeira]", faz recuar a multidão de negros que obstruem a passagem. Ele é seguido por um negro que solta fogos de artifício e, atrás dele, vêm três ou quatro negros dando cambalhotas, saltos, piruetas, "e mil outras artimanhas para animar a cena". Atrás segue, então, "a saída silenciosa dos amigos e das delegações que escoltam seriamente o corpo transportado em uma maca coberta com um manto mortuário".

A partir da imagem que mostra um plano geral do cortejo fúnebre, podemos ter uma noção ainda mais nítida daquilo que o artista francês observou no Rio de Janeiro entre as décadas de 1820 e 1830 . Visualizam-se sua ordenação e sequência e os principais personagens. À frente, vem o "súdito" responsável pelos fogos de artifício que abrem o préstito. Depois, aparecem os negros que dançam e fazem "mil artimanhas"; o "mestre de cerimônias" com seu "vime" [cacete] conduzindo o cortejo. Carregando o corpo, vêm as delegações de "outras nações africanas" e os "amigos"; é possível reparar que alguns trazem estandartes e bandeiras e que o cadáver é coberto por um manto decorado com uma cruz. Podemos notar ao fundo os indivíduos que tentam manter uma enorme multidão a certa distância.

É importante notarmos que, no relato de Debret, o cortejo fúnebre possui semelhanças e diferenças em relação aos Cucumbis descritos por Mello Moraes Filho. Primeiramente, o tema da morte ocupa papel central em ambas as tramas, sendo muito mais óbvio no caso do cortejo fúnebre 
descrito por Debret, já que só existe e tem sentido a partir da morte do rei ou de seu filho. Já no Cucumbi descrito por Mello Moraes, a morte não dá início ao préstito, porém é posta de forma dramática com o assassinato do filho do rei, o Mameto. Apesar de o tema da morte aproximar os dois cortejos, ela é tratada de forma diferente, pois ela é superada no Cucumbi, quando o feiticeiro revive o Mameto.

Os negros que dançam, fazem piruetas e cambalhotas estão presentes nas duas narrativas. É o Mameto quem ocupa esse papel no Cucumbi descrito por Mello Moraes, enquanto, no cortejo fúnebre de Debret, são os negros que dançam à frente do corpo do rei ou de seu filho morto, justamente a mesma posição em que aparecem os Mametos.

A participação de "delegações" de outros povos negros visitando o cadáver é bastante semelhante à embaixada que compõe o Cucumbi: representantes do reino que visitam outras cortes, levando suas insígnias, ou ainda há narrativas de embaixadas de vassalos que serão apresentados ao rei. ${ }^{9}$

Debret não gasta muitas linhas descrevendo os instrumentos que compunham esse cortejo, limitando-se a dizer que eram pouco sonoros e emitiam uma harmonia monótona e surda. Isso nos leva a crer que se tratasse de instrumentos de percussão, o que pode ser confirmado pela imagem a seguir, onde podemos visualizar um homem negro tocando uma espécie de tambor quadrado. A descrição de Mello Moraes sobre os instrumentos compreende tamborins, xequerês (chocalho de cobre), canzá (ganzá = maracá, chocalho), marimbas ( série de lâminas graduadas em escala, percutidas com duas baquetas e dispostas sobre cabaças ou tubos de metal), agogôs (duas campânulas de metal, tocadas por vareta, emitindo sons agudos) e pianos de cuia (cabaça grande, envolta num trançado de algodão, à semelhança de rede de pescaria, tendo presos pequenos búzios nos pontos de interseção das linhas) ${ }^{10}$ e o adufo. Este último instrumento, segundo descrição de Mario Frungillo, é bastante

9 Mario de Andrade, Dicionário musical brasileiro, Belo Horizonte: Itatiaia; São Paulo: USP, 1989; Luis da Câmara Cascudo, Dicionário do folclore brasileiro, Rio de Janeiro: INL, 1971 [1954]; Arthur Ramos, O folclore negro no Brasil, Rio de Janeiro: Casa do Estudante, [19--].

10 Notas de Arthur Ramos para o livro de Mello Moraes Filho, Festas e tradições. 


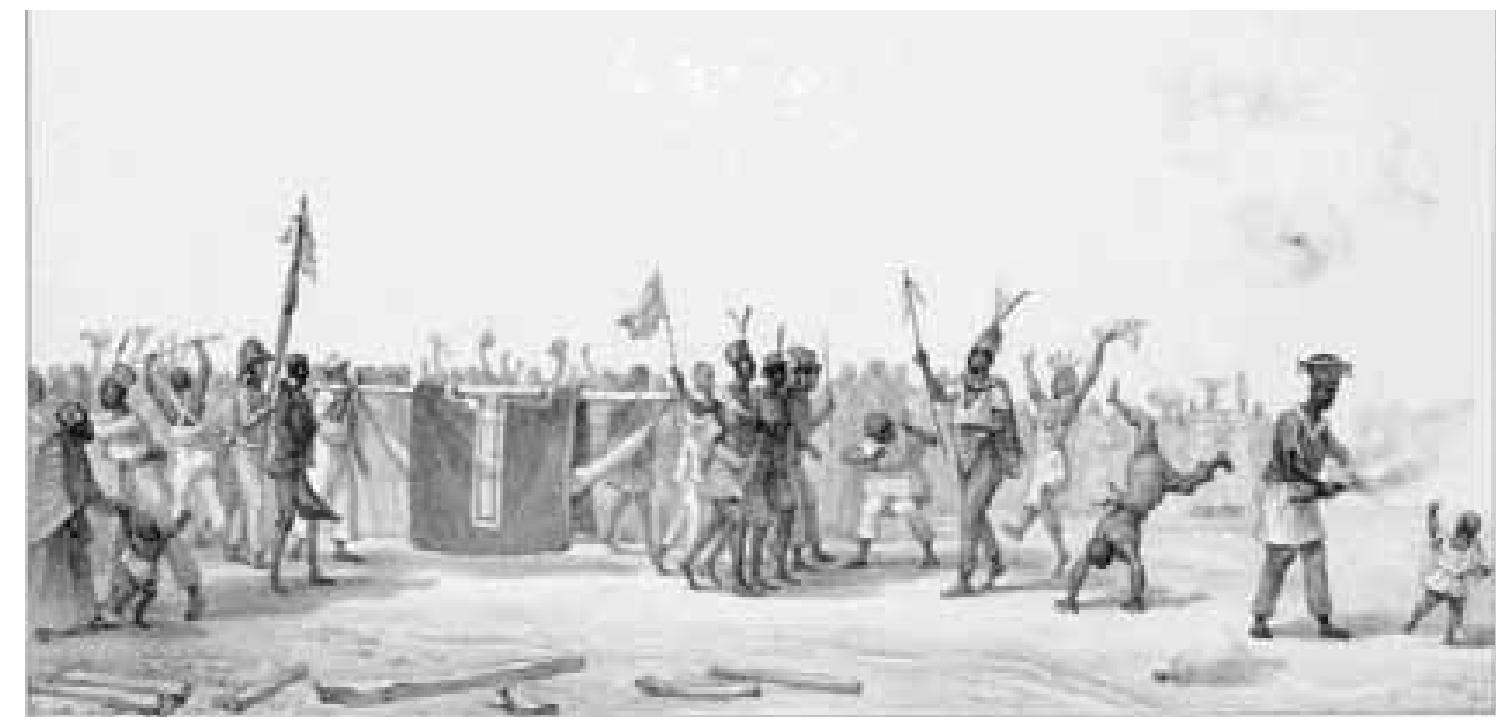

Figura 1 - Convoi fúnebre d'un fils de roi nègre

Fonte: Jean-Baptiste Debret, Voyage pitoresque et historique au Brésil. t. 3.

Paris: Firmin Didot Frères, Imprimeurs de l'Institute de France, 1839.

Prancha 16.

similar ao que aparece na imagem de Debret: tamborete quadrado que, por sua natureza artesanal, não possui sua pele muito esticada, produzindo, assim, sons graves. ${ }^{11}$

Entretanto, a partir das descrições de Mello Moraes sobre os Cucumbis do Rio de Janeiro não podemos afirmar que os grupos que saíam no carnaval com esse nome seriam apenas a reedição de cortejos fúnebres realizados por motivo de falecimento de membros de famílias reais africanas no Brasil na primeira metade do século XIX. Se encontramos semelhanças com o préstito fúnebre registrado por Debret - a presença do tema da morte, os negros fazendo piruetas, os instrumentos musicais e a visita de delegações - , as diferenças são marcantes, como, por exemplo, a presença da Rainha, a ressurreição, o feiticeiro poderoso que vence a morte e os próprios sentidos da festa - , encenando empreitadas vitoriosas de antepassados africanos, reforçando o poder de sua corte e a força de sua mística encarnada pelo Quimboto, o Feiticeiro.

${ }_{11}$ Mario D. Frugillo, Dicionário de percussão, São Paulo: Editora UNESP/Imprensa Oficial do Estado, 2003. 
Prosseguindo em seu artigo, Mello Moraes faz explícita associação entre os Cucumbis e os autos de Congo, afirmando que eles seriam iguais, tendo como única diferença o nome utilizado na Bahia (Cucumbi). Outros textos tornam essa relação ainda mais evidente. Luis Edmundo ${ }^{12}$ narra uma Congada saída da Igreja do Rosário, no tempo dos vice-reis (17631808) e afirma que "a tropilha folgaz dos negros vem cantando, a dançar, ao som de adufos, caxambus, xequerês, marimbas, chocalhos e agogôs", atraindo negros das mais variadas origens e grupos populares diversos:

[...] congos e moçambiques, monjolos e minas, quiloas e benguelas, cabindas e rebolas, de envolta com mulatos de capote, com ciganos e moleques, a turbamulta dos quebra-esquinas, escória das ruas, flor da gentalha e nata dos amigos do banzé". ${ }^{13}$

A Congada descrita por ele, que remontaria ao final do século XVIII, constitui-se de um grande grupo de homens e mulheres negras que saem às ruas da cidade para apresentar sua corte, que havia sido coroada na Igreja do Rosário: "Para tais solenidades, em tudo copiadas das que serviam à coroação dos verdadeiros reis, enfeitava-se toda a igreja, acendiam-se os altares e até repicavam os sinos".

O préstito era composto por uma banda de adufos, caxambus, xequerês, marimbas, chocalhos e agogôs, comandada pelo "Capataz". Em cima de andores, vêm o Rei e a Rainha, trajando seda, empunhando cetro e ostentando sobre a cabeça coroas de papelão. Ao chegar à frente do palácio do Vice-Rei (na atual Praça Quinze de Novembro), o préstito para, o Rei desce de seu pálio dançando, chacoalhando as luas e estrelas de metal presas à sua capa pesada. O Rei canta: "Sou rei do Congo / Quero brinca / Cheguei agora / De Portugá".

Nesse momento, surge em cena um dos personagens principais

\footnotetext{
12 Luis Edmundo, nascido no Rio de Janeiro em 26 de junho de 1878, foi jornalista, poeta, cronista, memorialista, teatrólogo e orador. Dedicou-se intensamente ao passado do Rio de Janeiro, cidade que amou e onde faleceu em 8 de dezembro de 1961. Foi cronista e pesquisador da cidade, publicando obras ainda hoje fundamentais para aqueles que se interessam pelo cotidiano carioca nos séculos passados. Ver Luiz Edmundo, O Rio de Janeiro do meu tempo, Rio de Janeiro: Imprensa Nacional, 1938, que versa sobre os costumes das populações do Rio de Janeiro na segunda metade do século XVIII.

13 Edmundo, $O$ Rio de Janeiro.
} 
da trama: o Mameto. Ele é o filho do Rei e da Rainha, e é assim descrito por Luis Edmundo:

O mameto, filho do rei, um molecote de dez anos, como os monarcas todo metido em sedas e com sua capa de belbute, logo que sentam em seus tronos o rei e a rainha, avança e, em círculos, a erguer os bracinhos tenros, põe-se a dançar, cantando em voz de falsete.

No instante em que o Mameto evolui em destaque na Congada, surge "um caboclo de olho trágico, vestido como cacique, e que desfere o tacape terrível sobre [sua] cabeça". ${ }^{14}$ Morto o filho do Rei, dança o caboclo e lamenta o coro da congada.

O Capataz participa ao Rei a notícia trágica, que imediatamente convoca o Quimboto para reviver seu filho. Luis Edmundo chama atenção para esse personagem:

Vale descrição especial a figura do bruxo ressuscitador que aparece. É um negro esplêndido de porte, ágil dançarino, trazendo, a tiracolo, uma cobra viva. Nos braços mostra grandes braceletes de miçangas e tem as pernas envoltas em peles de anta e de jaguar. Impressiona.

O Quimboto dança e canta ao redor do corpo do Mameto que, aos poucos, torna à vida. O Caboclo, "louco de espanto", tenta atacar novamente com seu tacape, mas dessa vez o feiticeiro, "num passo de chula", fulmina-o com o olhar, "que é uma estocada". "Triunfo absoluto do quimboto". Sua recompensa é ter a mais linda das princesas como noiva, terminando a farsa em casório.

As descrições de Luis Edmundo sobre uma Congada e as de Mello Moraes sobre os Cucumbis são muito similares. Os versos registrados por ambos praticamente não se alteram, os instrumentos musicais também. Os personagens são os mesmos, assim como o enredo é praticamente igual.

Mas é importante notar que Luis Edmundo narra uma Congada, cujo tema central é a coroação do rei do Congo e seu desfile de consagração no período colonial. Os Cucumbis que desfilavam nos carnavais

14 Sobre a presença do Caboclo no Cucumbi, ver Mary Karash, A vida dos escravos no Rio de Janeiro, 1808-1850, São Paulo: Companhia das Letras, 2000. 
da década de 1880 - que chamarei, a partir de agora, de Cucumbis Carnavalescos, em oposição aos Cucumbis coloniais - dialogam com um contexto social, político e cultural muito diverso, e por isso seus sentidos também são distintos.

Para entendermos melhor essas diferenças, devemos ressaltar a distância temporal existente entre os dois. As congadas do período colonial possuíam sentido diverso. Estavam quase sempre associadas às irmandades religiosas, que representavam uma possibilidade de distinção social de escravos e negros livres numa sociedade de Antigo Regime. Aumentavam as chances de acesso ao batismo e a um sepultamento cristão, além de possibilitar a formação de alianças e identidades aos africanos recém-chegados ao Brasil. As irmandades destinadas aos homens de cor, escravos e livres, representavam um dos principais caminhos de movimentação dentro da sociedade estamental do Brasil colonial. Participar de uma irmandade possibilitava um atalho para escravos, forros e negros livres ao acesso às distinções sociais, como ressaltou Mariza Soares. ${ }^{15}$

No interior dessas irmandades, também havia uma corte, onde o Rei era eleito e coroado em uma grande festa. O recolhimento de esmolas em nome do orago promovia tanto a manutenção da corte e da irmandade, quanto o custeio de funerais, auxílios médicos e a compra da liberdade de irmãos cativos.

Marina de Mello e Souza, em seu estudo sobre a coroação de reis negros no Brasil, trouxe grandes contribuições para nosso entendimento das formas de associação e construção de identidades entre escravos, libertos e negros livres por meio dessas práticas culturais. A coroação de reis negros, muitas vezes permitidas pelas autoridades desde o período colonial, funcionava como caminho de formação de alianças, não apenas étnicas. A coroação de reis possibilitava um momento de agregação, pois a essa festa afluíam escravos de múltiplas origens, assim como negros livres nascidos no Brasil, e identidades eram construídas:

Na definição de alianças internas à comunidade negra, afinidades trazidas da África, como pertencimento a uma mesma religião ou macrogrupo

\footnotetext{
15 Mariza Soares, Devotos da cor: identidade étnica, religiosidade e escravidão no Rio de Janeiro do século XVIIII, Rio de Janeiro: Civilização Brasileira, 2000.
} 
cultural, eram invocadas ao lado de afinidades tecidas no processo de elaboração de novas comunidades na sociedade colonial. ${ }^{16}$

Entretanto, sob o manto do rei do Congo, ainda seguindo as palavras de Marina de Mello e Souza, os demais reis de nações africanas vão desaparecendo ao longo do período colonial. As explicações para tal processo de predominância congolesa, que resulta no monopólio do rei do Congo sobre as coroações no século XIX, devem ser "buscadas na história das relações entre Portugal e a África Centro-Ocidental". ${ }^{17}$

As características culturais compartilhadas pelos povos de origem banto, oriundos da África Centro-Ocidental, tiveram papel principal na elaboração de novas identidades na sociedade colonial. Mello e Souza elenca um rol dessas semelhanças relativas às formas de organização social, política e religiosa dos povos bantos..$^{18}$

Complementarmente, Robert Slenes afirma que

[...] dos africanos trazidos para o sudeste brasileiro, em torno de $93 \%$ entre 1791 e 1811 e $75 \%$ ente 1811 e 1850 vieram da África central ocidental; desta forma a grande maioria das pessoas destinadas para as senzalas nessa parte do Brasil descobriu desde o início, no navio negreiro ou na jornada anterior rumo a costa atlântica, que tinha muito em comum. ${ }^{19}$

O reino do Congo, citado pela autora como exemplo de organização social, política e religiosa complexa que partilhava desses pressupostos culturais, e por Slenes como principal fonte de escravos

\footnotetext{
16 Marina de Mello e Souza, Reis negros no Brasil escravista: história da festa de coroação do rei congo, Belo Horizonte: Ed. UFMG, 2006, p 254.

17 Souza, Reis negros, p. 258.

18 "Organização dos grupos em torno de linhagens; [...] o agrupamento de linhagens em torno de um chefe, que também detinha atributos religiosos, podendo essa estrutura vir a constituir um reino, como no caso do Congo [...]; o culto aos ancestrais; a divisão do mundo entre aquele habitado pelos vivos e o habitado pelos mortos, do qual vinha todo o conhecimento; o controle dos ritos religiosos por especialistas; a utilização de objetos magicamente confeccionados, que incorporavam atributos de espíritos específicos [...]; uma maleabilidade cultural que levava a frequentes transformações das religiões, dentro do parâmetro maior do complexo ventura/desventura e fazia com que elementos novos fossem facilmente incorporados. Souza, Reis negros, p. 259.

19 Robert Slenes, “Eu venho de muito longe, eu venho cavando': jongueiros cumba na senzala centro-africana", in Silvia Hunold Lara e Gustavo Pacheco (orgs.), Memória do jongo: as gravações históricas de Stanley Stein. Vassouras, 1949 (Rio de Janeiro: Folha Seca; Campinas: CECULT, 2007), p. 116.
} 
para o Sudeste brasileiro até meados do século XIX, tornou-se símbolo para os negros provenientes da África Centro-Ocidental de reino forte e respeitado por europeus e africanos. Seu processo de cristianização precoce, ainda no século XVI, lhe conferiu ares diferenciados no interior do continente africano e abriu novas formas de prestígio e poder. ${ }^{20}$ Apesar de seu enfraquecimento político com as guerras civis que sofreu entre os séculos XVII e XVIII, ${ }^{21}$ a imagem do rei do Congo, católico e poderoso, continuou a ser um elemento forte o suficiente para estar presente nas festas e histórias dos negros no Brasil até hoje.

Sendo assim, a coroação do rei do Congo foi uma dentre muitas possibilidades de formação de identidades do lado de cá do Atlântico. Conseguia catalisar as atenções de múltiplos grupos de escravos, à medida que muitos deles puderam se sentir pertencentes àquelas práticas. Com o passar do tempo, as "diversidades foram sendo apagadas em favor de uma identidade comum, historicamente construída, de negros católicos", ${ }^{22}$ mas, devo acrescentar, sob a predominância das características culturais dos povos bantos.

As coroações de reis do Congo descritas por Mello e Souza compreendem, além do ato da coroação em si, uma embaixada, em que ocorre um embate entre o rei do Congo e enviados de um reino estrangeiro. A partir dela, afirma a autora, podemos encontrar os caminhos para compreender o processo de constituição de uma identidade católica negra e também nela encontramos com mais clareza elementos de "uma história e uma organização social africanas". ${ }^{23}$

As embaixadas eram comuns entre os reinos africanos e também europeus. Por meio delas, estabeleciam-se relações comerciais, políticas e militares, firmavam-se casamentos e outros pactos sociais. Nas festas coloniais, as embaixadas consistiam em préstitos formados por uma corte, ou representantes dessa corte, que se deslocavam como se fossem

\footnotetext{
20 Souza, Reis negros.

21 John Thornton, The Kingdom of Kongo: Civil War and Transition, 1641-1718, Madison: University of Wisconsin Press, 1983; John Thornton, A África e os africanos na formação do mundo atlântico, 1400-1800, Rio de Janeiro: Elsevier, 2004.

22 Souza, Reis negros, p. 302.

23 Souza, Reis negros, p. 302.
} 
encontrar-se com outro reino africano. A centralidade das embaixadas na eleição do rei do Congo no Brasil demonstra que, a partir da incorporação de elementos da história africana, essa festa tornou-se "um lugar de memória, no qual o passado era periodicamente revivido, contribuindo assim para a afirmação de uma identidade". ${ }^{24}$

Portanto, quando Luis Edmundo relata a Congada no tempo dos vice-reis, ele está tratando de uma manifestação associada a um contexto colonial, em que ainda não existe um movimento em prol da abolição da escravidão explícito e consciente, em que os escravos são maioria entre a população negra, e a existência da Congada reflete um dos mais importantes caminhos para galgar posições e distinções sociais, mesmo que apenas entre a própria população negra e mestiça: a participação em uma irmandade religiosa.

$\mathrm{O}$ arcabouço cultural produzido ao longo dos séculos de contato com a África, principalmente com as culturas dos povos bantos, continuou a informar as ações dos membros dos Cucumbis Carnavalescos na década de 1880; a presença do rei do Congo no préstito atraía a atenção de inúmeros descendentes de africanos que entendiam as bases das culturas bantos; ao mesmo tempo, porém, eles dialogavam com um contexto completamente diferente e novo. Tanto a festa carnavalesca estava passando por profundas inovações (com o auge das grandes sociedades, o empenho de jornalistas e autoridades para enfraquecer práticas encaradas como "bárbaras" e sua ascensão à festa nacional), quanto a sociedade carioca, que experimentava a ruína do escravismo e todas as discussões sobre qual nação deveria ser engendrada nesse processo.

Seria, então, o Cucumbi Carnavalesco uma manifestação trazida pelos negros baianos que chegaram ao Rio de Janeiro após 1850? É preciso tentar uma aproximação com o Cucumbi ainda nas terras da Bahia.

Segundo Manuel Querino, em seu livro A Bahia de outrora, "O Cucumbi não passava de uma recordação das festas africanas, é certo". ${ }^{25}$ Os instrumentos eram similares aos descritos por Luis Edmundo e Mello

\footnotetext{
24 Souza, Reis negros, p. 304

25 Manuel Querino, A Bahia de outrora, Salvador: Progresso, 1946, p. 63. As citações seguintes são dessa mesma obra, pp. 63-6.
} 
Moraes Filho; o grupo compunha-se de indivíduos armados de arcos e flechas, "capacete, braços, pernas e cintura enfeitados de penas, saiote e camisa encarnados, corais, missangas e dentes de animais no pescoço, à feição indígena"; outros vestiam "corpete de fazenda de cor, saieta de cetim ou cambraia, com enfeites de velbutina azul e listas brancas, num estilo bizarro".

Outras semelhanças podem ser encontradas entre o Cucumbi descrito por Querino e os descritos por Mello Moraes. No enredo, a "festança" transcorre normalmente, com os instrumentos tocando, e as grimas (pedaços de madeira) sendo batidas umas nas outras, quando então um "indígena [é] acusado de haver enfeitiçado o guia, que devido a essa circunstancia, se achava em estado mortal”. Então o feiticeiro

[...] se delibera a curar o guia, que simula agonizante. Para isso, no meio de grande algazarra, toma de uma bolsinha e com ela toca levemente as pernas e braços do doente, dando movimento desordenado ao corpo, entoando cantigas lúgubres. Ao depor a bolsinha ou contra-feitiço nos lábios do guia, este recobra os sentidos, e todos se entregam às maiores expansões de regozijo.

Porém, esse Cucumbi não possui Mameto [seria o guia?], nem aparece a Rainha ou o Rei (exceto no verso inicial: "Viva nosso rei, Preto de Benguela, Que casou a princesa C'o infante de Castela."). Querino, que foi "artista, funcionário da secretaria da agricultura, diretor do clube carnavalesco Pândegos d'África, professor, associado da Sociedade Libertadora Baiana, jornalista da Gazeta da Tarde", merece ser observado com atenção. ${ }^{26}$

Esse relato sobre os Cucumbis da Bahia de "outrora" é produto de um conhecedor profundo dos costumes das populações negras da Bahia. Logo, a inexistência de termos como Mameto, Quimboto, Caboclo e o

\footnotetext{
26 Segundo Wlamyra Albuquerque, Querino forjou sua imagem pública em sua empedernida atuação na campanha abolicionista, sua participação em associações operárias e em suas pesquisas sobre a cultura negra na Bahia. Sendo negro, sua atuação contribui para combater a ideia de que os brancos eram responsáveis pelas ações abolicionistas. Defendia que o negro merecia lugar de destaque "como fator da civilização brasileira", pois foi o seu trabalho que sustentou por séculos "a nobreza e a prosperidade do Brasil". Ver Wlamyra Albuquerque, O jogo da dissimulação: abolição e cidadania negra no Brasil, São Paulo: Companhia das Letras, 2009. pp 86-7.
} 
silêncio sobre um enredo mais detalhado dessa prática também nos diz muita coisa. É provável que os Cucumbis, sob esse nome e no modelo narrado por Querino, não existissem mais na Bahia em finais do século XIX, e sua narrativa tenha sido feita com base em memórias antigas ou relatos de velhos participantes. Tal argumento é reforçado pelo livro de Nina Rodrigues, Os africanos no Brasil, quando afirma que nunca viu Cucumbi na Bahia. ${ }^{27}$ Por outro lado, podiam existir de forma tão marginal que nem Nina Rodrigues os enxergou nem Manuel Querino pôde captar seus personagens e enredo mais minuciosamente.

Nessa leitura de memorialistas, folcloristas e viajantes sobre os Cucumbis, podemos chegar a algumas conclusões. A hipótese defendida por Mello Moraes para o ressurgimento dos Cucumbis no carnaval do Rio de Janeiro coloca, na ação de baianos filhos de africanos trazidos pelo tráfico interno, a liderança nessa "inovação". ${ }^{28}$

Minha tese difere da análise de Mello Moraes, apesar de não negar a importância de "baianos" para as transformações culturais e sociais do Rio de Janeiro pós-1850. Porém, eles representam apenas mais um elemento de composição do amplo caldeirão cultural que era a cidade do Rio de Janeiro em 1880. Como afirma Tiago de Melo Gomes, os "baianos" encontraram no Rio um rico universo cultural "no qual outros grupos imprimiram suas marcas" e tiveram, assim, que dialogar com as tradições já existentes. ${ }^{29}$ As inúmeras tradições culturais da cidade eram robustas o suficiente para se transformar e interagir com as demais, dando origem a formas e nomes novos para antigas práticas ou práticas novas para antigos nomes.

\footnotetext{
27 Nina Rodrigues, Os africanos no Brasil, São Paulo: Nacional; Brasília: INL, 1976. p. 181.

28 Mello Moraes Filho tenta dar conta das origens dos Cucumbis em seu artigo e descreve o seu enredo e seus instrumentos, assim como reproduz alguns versos. Seu texto reforça a noção de que esses Cucumbis são exemplos de um passado inofensivo, de tradições que devem ser reconhecidas e valorizadas, mas que estão fadadas ao desaparecimento. $\mathrm{O}$ autor buscava os elementos formadores do povo e da nacionalidade brasileira. Diferentemente de tantos outros intelectuais, não pretendia silenciar tradições africanas ou mestiças. Como afirmou Martha Abreu, sua obra incorpora e valoriza, de forma saudosista e idealizada, muitas das tradições africanas. Contudo, seu lugar é no passado, pois o presente e o futuro estariam reservados aos diversos encontros e contatos entre múltiplas tradições. Martha Campos Abreu, O Império do Divino: festas religiosas e cultura popular no Rio de Janeiro, 1830-1900, São Paulo: Nova Fronteira, 1999.

29 Tiago de Melo Gomes, "Para além da casa da Tia Ciata: outras experiências no universo cultural carioca, 1830-1930”, Afro-Ásia, n. 29-30 (2003), p. 179.
} 
Os Cucumbis Carnavalescos não representam apenas uma reprodução de antigas festas coloniais. Eles eram uma manifestação mais ampla, uma elaboração criativa de seus participantes estabelecendo um diálogo entre as novas formas de se brincar o carnaval da década de 1880 com os elementos culturais presentes entre as culturas negras da cidade. Elementos das congadas, dos reisados, das festas das irmandades religiosas, dos cortejos fúnebres, de embaixadas africanas, e também referências à tradição religiosa banto (o complexo ventura/desventura, o feiticeiro, a Calunga, um cristianismo africano) e a história da África (o reino do Congo, a rainha Ginga, a travessia do Atlântico) entravam em contato com as formas europeizadas de se brincar o carnaval (os préstitos com estandartes que dançavam em frente às redações dos jornais, o passeio pela Rua do Ouvidor).

Um indício bastante interessante das diferenças entre os Cucumbis Carnavalescos e grupos majoritariamente compostos por baianos pode ser encontrado em relatos de Donga e Vagalume sobre o início do século XX. Um Afoxé criado em 1900, por baianos residentes no Rio, "fazia a crítica dos Cucumbis", segundo Donga. Vagalume completa que tal grupo "tinha por finalidade criticar os africanos residentes nesta cidade [...] as críticas consistiam em reproduzir o tipo deste ou daquele africano que tivesse influência". ${ }^{30}$ Parodiavam canções, vestimentas, trejeitos e hábitos dos Cucumbis Carnavalescos e seus membros. Segundo Maria Clementina Pereira Cunha, "esses grupos [afoxés de baianos] colocavam-se como contraposição carnavalesca aos 'africanismos' cariocas e até hostilizavam tradições negras locais, talvez decodificadas como práticas 'antigas" ". ${ }^{31} \mathrm{Ou}$ seja, grupos explicitamente ligados a imigrantes baianos não se reconheciam na tradição dos Cucumbis cariocas, manifestando tal postura publicamente.

O grupo fotografado por Cristiano Júnior na Rua da Quitanda, no carnaval de 1868, nos ajuda a refletir ainda mais sobre as transformações dos Cucumbis na década de 1880. A foto mostra uma "corte africana"

\footnotetext{
30 Apud Jota Efegê, Ameno Resedá - O rancho que foi escola. Documentário do carnaval carioca, Rio de Janeiro: Letras e Artes, 1965, pp. 68-9.

31 Cunha, Ecos da folia, p. 213. 


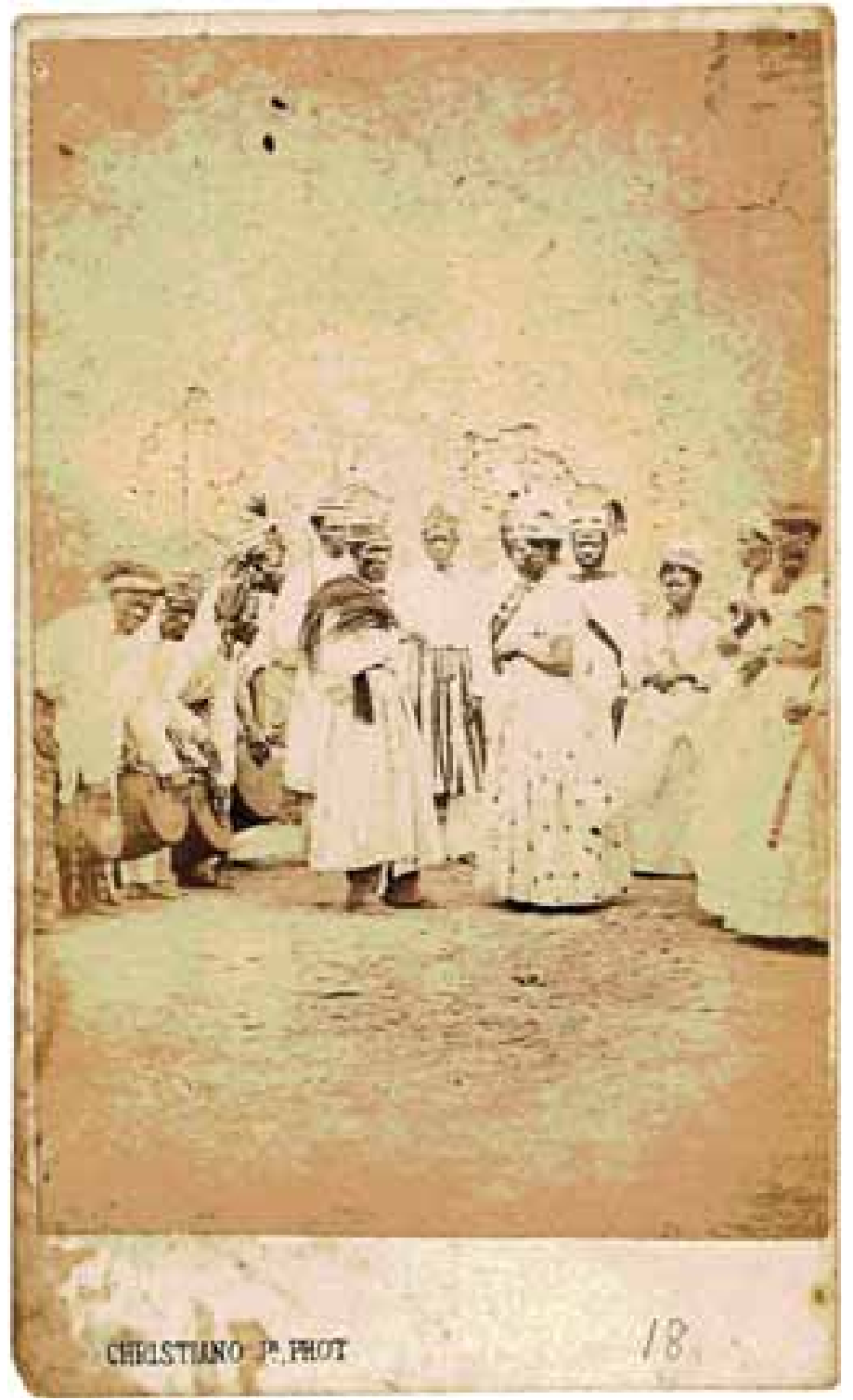

Figura 1 - Cucumbi fotografado por Christiano Jr. na Rua da Quitanda em 1868 Fonte: Escravos brasileiros no século XIX: a fotografia de Christiano Jr. São Paulo: Ex-Libris, 1988. Prancha 73. Copyright Serviço do Patrimônio Histórico e Artístico Nacional. 
de Cucumbi, onde vemos 14 pessoas negras vestidas de branco, com algumas penas nos chapéus. À frente estão o possível rei e a rainha, do lado esquerdo, quatro homens tocam tambores, do lado direito, há quatro mulheres e, atrás, mais quatro homens. É possível notar que muitos deles (inclusive o rei) estão descalços, o que aponta sua condição cativa, vestidos de camisas brancas, calças e algumas penas.

Apesar de ser uma corte e de Cristiano Jr. tê-los intitulado Cucumbis, esse grupo é muito diferente daqueles que encontramos na década de 1880. Primeiro não vemos os "índios", tão característicos dos Cucumbis Carnavalescos. Os instrumentos musicais se resumem a tambores iguais, sem chocalhos, tamborins, agogôs, pianos de cuia e outros. Não é possível distinguir o feiticeiro, com suas cobras e amuletos, nem o Caboclo, índio guerreiro que carrega seu tacape. As descrições da década de 1880 falam em grupos de cinquenta pessoas, com muitas "mulatas formosas", com pequena orquestra de "instrumentos desconhecidos e originais". Não aparece também o Mameto, jovem negro dedicado às piruetas e acrobacias.

O Cucumbi registrado por Cristiano Jr. se assemelha muito mais às congadas e folias das irmandades religiosas do período, que contribuíram significativamente para a elaboração criativa que originou os Cucumbis Carnavalescos da década de 1880 . Tal constatação reforça a tese de que foram intensas as transformações pelas quais passaram, entre as décadas de 1860 e 1880, as práticas que utilizaram o nome de Cucumbi.

Portanto, mesmo com as muitas referências sobre os Cucumbis que vimos até aqui, não temos como afirmar que o Cucumbi Carnavalesco do Rio de Janeiro na década de 1880 se restringia apenas a um significado ou prática festiva. Sua execução e elaboração ultrapassam todos os sentidos isolados dessas manifestações descritas até aqui. Não são coroações do rei do Congo, não são cortejos fúnebres e também não são apenas reedições dos Cucumbis baianos (como Mello Moraes sugere). Para nos aproximarmos dos possíveis sentidos dessa prática devemos inicialmente analisar como foram representados nos jornais coevos. 


\section{Os Cucumbis na década de 1880: do "Congo" à Rua do Ouvidor}

Durante os árduos - porém divertidos - meses em que estive analisando os rolos de microfilmes do Jornal do Comércio, da Gazeta da Tarde e da Gazeta de Notícias, além da Revista Ilustrada, preservados pela Biblioteca Nacional, pude me sentir, em alguns momentos, como um estrangeiro que recebia diariamente os exemplares desses periódicos sobre uma cidade estranha e distante. Lia, como um forasteiro do tempo, sobre essa festa que mobilizava grande parte dos habitantes desse tal de Rio de Janeiro do passado. Com o "passar dos anos", acabei me familiarizando com os seus personagens principais e suas práticas mais corriqueiras, inclusive pude identificar os temores que algumas delas causavam aos distintos jornalistas da Corte imperial.

A Gazeta de Notícias, a Gazeta da Tarde e a Revista Ilustrada possuíam estreitas relações com os movimentos abolicionistas, principalmente aqueles de viés mais moderado e legalista. A Gazeta de Notícias foi a primeira grande folha diária a defender o abolicionismo. Havia sido fundada em 1876 por Ferreira de Araújo e representou correntes abolicionistas mais moderadas, contudo, ainda publicava anúncios de escravos fugidos, aluguel e venda de cativos, pois dependia de anunciantes. ${ }^{32}$ Segundo Nelson Werneck, a Gazeta de Notícias "era, realmente, jornal barato, popular, liberal, vendido a 40 réis o exemplar". ${ }^{33}$

A Gazeta da Tarde, propriedade de José do Patrocínio a partir de 1881, abertamente apresentava maior identificação com os abolicionistas atuantes na imprensa e na esfera política ${ }^{34} \mathrm{Em}$ sua redação, havia sido fundada, em 1883, a Confederação Abolicionista. Por conta dessa afinidade ideológica, não aceitava a publicação de anúncios de escravos fugidos, ou de aluguel ou venda de cativos.

A Revista Ilustrada era propriedade de Angelo Agostini, artista abolicionista renomado no Rio de Janeiro. Fundada em 1876, atingiu logo

\footnotetext{
32 Humberto Fernandes Machado, "Palavras e brados: a imprensa abolicionista do Rio de Janeiro, 1880-1888" (Tese de Doutorado, Universidade de São Paulo, 1991).

33 Nelson Werneck Sodré, História da imprensa no Brasil, São Paulo: Mauad, 1994, p. 257.

34 Machado, "Palavras e brados".
} 
grande popularidade e conseguiu manter sua independência dos anunciantes, desfrutando de liberdade significativa ao abordar temas políticos cruciais do Império. ${ }^{35}$ A atuação de Agostini no movimento abolicionista do Rio de Janeiro foi marcante, assim como as páginas de sua revista. ${ }^{36}$

Apesar de obviamente apresentarem conflitos internos e diferenças entre si, esses três órgãos da imprensa carioca possuíam características ideológicas bem próximas daquelas defendidas por abolicionistas atuantes na cidade do Rio de Janeiro.

Como que num outro extremo desse conjunto de fontes, encontramos o Jornal do Comércio. Mantendo sua postura conservadora, mais alinhada com os grupos sociais escravocratas, praticamente ignorava as lutas pela liberdade no carnaval e no Brasil. Até os últimos suspiros da escravidão, continuou publicando anúncios de compra, venda e aluguel de escravos, assim como recompensas para a captura de escravos fugidos. ${ }^{37}$ Nos dias de carnaval, valorizava também as grandes sociedades, mas não apresentava vínculos ideológicos mais estreitos, justamente pela sua distância dos ideais abolicionistas. Logo, a própria imprensa do período apresentava divergências políticas e de variados projetos de nação e de carnaval.

Entretanto, compartilhavam olhares estereotipados sobre a cultura negra, valorizando padrões ocidentais brancos. Mesmo aqueles que defendiam o fim da escravidão raramente escapavam de explicações racializadas ou que, pelo menos, ajudavam a compor imagens de inferioridade cultural para a população negra.

No carnaval de 1884, timidamente, deparei-me com uma nova palavra nesses jornais. Sem nenhuma explicação, sem mais nem menos, diluído na primeira página, entre as demais notícias sobre o carnaval, no dia 24 de fevereiro, o Jornal do Comércio publicou a seguinte nota: "Percorreram também diversas ruas [o] grupo dos Pirilampos, Flor de Netuno, Cavalheiros de S. Potino, Flor de Catumby, Piratas do Amor, Quicumby (Caboclos), Bumba meu boi e outros". ${ }^{38}$

35 Sodré, História da imprensa, pp. 249-52; Marcelo Balaban, "O poeta do lápis: a trajetória de Angelo Agostini no Brasil Imperial, São Paulo e Rio de Janeiro, 1864 e 1888” (Tese de Doutorado, Universidade Estadual de Campinas, 2005).

36 Balaban, "O poeta do lápis", p. 6.

37 Balaban, "O poeta do lápis", p. 6.

38 Jornal do Comércio, 24 de fevereiro de 1884, Biblioteca Nacional, Seção de Periódicos. 
Para mim, fictício estrangeiro a ler jornais do Rio de Janeiro, o aparecimento desse Quicumby no Jornal do Comércio não representaria nada além de mais um grupo carnavalesco carioca com nome exótico. Sobretudo, por ele ter aparecido esse ano apenas nesse jornal e por eu não ter encontrado nenhuma referência a Cucumbi entre 1879 e 1883 nos periódicos consultados.

Porém, entre 1884 e 1888, diversas novas informações apareceriam nos jornais sobre os Cucumbis Carnavalescos. Enquanto "leitor estrangeiro", pude descobrir que traziam "uma dama que vinha vestida de rainha e um homem com umas barbas muito grandes e muito pretas, que devia ser o rei". Vestiam-se de saiotes e turbantes de plumas e utilizavam o artifício de dançar na frente das redações dos jornais, na Rua do Ouvidor, como no caso da Iniciadora Cucumbis em 1886, quando, em frente à Gazeta da Tarde:

[...] cumprimentou as redações dos jornais dançando e cantando, agitando a pluma de seus cocares, estando todos os sócios rica, luxuosamente mesmo fantasiados. Em frente ao edifício da nossa folha, demoraram-se por longo espaço de tempo, dando vivas a José do Patrocínio e a seus companheiros de trabalho. ${ }^{39}$

Desfilar pela Rua do Ouvidor (e saudar as redações dos jornais nela sediadas) era atitude comum entre os grupos que colocavam seus préstitos na rua durante o carnaval. Inspiravam-se nas grandes sociedades carnavalescas - Fenianos, Democráticos e Tenentes do Diabo - que se encontravam no auge de sua popularidade e serviam de exemplo para centenas de grupos. Essas grandes sociedades carnavalescas estavam bastante afinadas com os interesses e projetos de grande parte da imprensa carioca. Defendiam caminhos de modernização e "civilização" para a nação brasileira, caminhos esses que passavam tanto pela abolição da escravidão e proclamação da república quanto pela reformulação das práticas festivas brasileiras, que seriam "atrasadas" e incompatíveis com o ideal de progresso.

O carnaval de inspiração veneziana deveria substituir o bárbaro

\footnotetext{
39 Gazeta da Tarde, 10 de março de 1886, Biblioteca Nacional, Seção de Periódicos.
} 
entrudo e as demais brincadeiras populares, sobretudo as de matriz africana ${ }^{40}$ A Rua do Ouvidor seria, então, o melhor espaço para tal empreitada, na medida em que era considerada a "artéria da civilização" no Rio de Janeiro e concentrava inúmeras lojas europeias e de artigos de luxo, além das redações dos principais jornais e revistas. Seus jornalistas e redatores compartilhavam grande parte dos ideais progressistas das grandes sociedades carnavalescas, e muitos deles eram seus membros mais atuantes. ${ }^{41}$ Eram comuns as homenagens recíprocas entre Fenianos, Democráticos e Tenentes do Diabo e os grandes jornais da Corte, principalmente aqueles mais identificados com causas como a abolição, a república e a defesa de projetos modernizadores para o Brasil, como a Gazeta de Notícias e a Gazeta da Tarde.

Portanto, quando as muitas sociedades que eram criadas anualmente no Rio de Janeiro para desfilar no carnaval - não apenas os Cucumbis - disputavam espaço na estreita Rua do Ouvidor e paravam diante dos jornais para saudá-los, elas estavam se valendo das estratégias das grandes sociedades, mas com outros objetivos e com modos e vestimentas muito distantes dos de Veneza. Visavam, sobretudo, a ganhar territórios simbólicos na festa, conseguir espaço nas páginas dos jornais, ter seu esforço e dedicação reconhecidos publicamente e ser elevadas ao rol dos grupos de destaque. Com os Cucumbis Carnavalescos não foi diferente. A incorporação de expedientes das grandes sociedades servia para que fossem mais vistos e reconhecidos e, ao mesmo tempo, impedia que fossem completamente silenciados ou perseguidos pelas autoridades. Dessa forma, também poderiam expor publicamente preferências e identidades, além de suas próprias elaborações criativas sobre o carnaval.

É José do Patrocínio o grande homenageado pela Iniciadora dos Cucumbis naquele ano de 1886. Esse personagem é simbólico para entendermos a escolha da Iniciadora dos Cucumbis. José do Patrocínio foi um dos mais atuantes abolicionistas do Rio, fundou a Confederação Abolicionista em 1883, justamente no prédio da redação da Gazeta da Tarde (jornal que ele possuía desde a morte de Ferreira de Menezes em

\footnotetext{
40 Nepomuceno, "Carnavais da abolição", especialmente o capítulo "Diabos encarnados", pp. 106-66.

41 Cunha, Ecos da folia, especialmente o capítulo 2, "Batalha sem confetes", pp. 87-149.
} 
1881). Em 1886, foi eleito vereador da Câmara Municipal do Rio de Janeiro, ao mesmo tempo em que expandia suas atividades de abolicionista para além dos limites de seu jornal: promovia meetings, comícios em teatros e praças, além de auxiliar fuga e acoitamento de escravos. ${ }^{42}$

Quando uma sociedade carnavalesca que nunca havia aparecido em nenhum jornal dedica parte de seu préstito a saudar José do Patrocínio e "seus companheiros de trabalho", ela quer passar uma mensagem. Deseja ser associada à sua imagem ou, pelo menos, fazer saber que compartilha de seus ideais. E a principal bandeira de Patrocínio, e também da Gazeta da Tarde, era a abolição da escravidão. Parece que a estratégia da Iniciadora dos Cucumbis funcionou bem, pois ela entrou no rol das sociedades que continuariam a figurar nos jornais pelos anos seguintes.

$\mathrm{O}$ ano de 1887 traz novas informações para o leitor. O Jornal do Comércio enumera, entre os grupos que desfilaram nos três dias desse carnaval, os Cucumbis Carnavalescos, Iniciadores dos Cucumbis, Filha dos Iniciadores dos Cucumbis e o Triunfo dos Cucumbis. São os mesmos grupos que aparecem na Gazeta de Notícias, entretanto, essa folha publica algumas informações adicionais sobre eles, diferentemente do Jornal do Comércio. Afirma a Gazeta de Notícias:

Gente bem vestida esta [dos Cucumbis] e que dançava bem, como provou, dançando em frente a cada uma das redações dos jornais. Acompanhava o grupo uma porção de pretas, carregando criancinhas de peito. O que prova que os Cucumbis, além das festas do carnaval, tem outras coisas em que se ocuparem. [... $]^{43}$

Comumente, era ressaltada a capacidade de cantar e dançar dos membros dos Cucumbis, porém nessa descrição há um componente novo: a cor da pele. Segundo o jornalista "uma porção de pretas" acompanhava o grupo carregando criancinhas de colo. Pela primeira vez, desde 1884, quando da primeira aparição dos Cucumbis, nos jornais analisados, se explicitava a cor da pele de parte das pessoas que compunham esses grupos: elas eram pretas. Como se não bastasse esse comentário, o

\footnotetext{
42 Machado, "Palavras e brados".

43 Gazeta de Notícias, 21 de fevereiro de1887, Biblioteca Nacional, Seção de Periódicos.
} 
jornalista prossegue afirmando - como se respondesse àqueles que duvidavam - que aquelas pretas dos Cucumbis também tinham outras coisas com que se preocupar, além de cantar e dançar vestidas de plumas durante o carnaval.

Apesar dos elogios ao bom desempenho dos membros dos Cucumbis ao dançar e cantar, o comentário racializado do jornalista começa a evidenciar elementos até então invisíveis para quem só tomou conhecimento dos Cucumbis por meio dos caracteres impressos.

O Jornal do Comércio, em sua primeira página de 14 de fevereiro de 1888, publica um artigo no qual faz um exame dos desfiles de nada menos que quatro Cucumbis diferentes que passaram em frente à sua redação na segunda-feira de carnaval. O texto abre novas possibilidades de compreensão de quem são e quais os principais intentos dos membros dos Cucumbis carnavalescos do período, por isso, vale a pena reproduzi-lo:

Desfilaram pela rua do Ouvidor: [...] os Cucumbis Africanos, que, vestidos como nos países africanos, saudaram a imprensa e o Imperador do Brasil, entoando nessa ocasião cânticos originais, ao som de instrumentos não menos originais, parando de vez em quando para fazer prolongadas reverências, dando o mote da cantiga: A África sempre foi livre; [...]

[Desfilaram também] os Cucumbis Carnavalescos, fantasiados também com roupas africanas; na frente vinham alguns sócios fantasiados de Índios, os quais faziam manobras selvagens, deitando-se as vezes no chão para ouvir o que ia ao longe. No centro do grupo estava a rainha, coberta por um grande manto, cujas pontas eram seguras por dois Cucumbis. Paravam em frente aos jornais, cantavam e dançavam à moda africana. Fizeram também a sua passeata os Lanceiros Cucumbis carnavalescos, que como os dois outros grupos congêneres e do mesmo nome apresentaram-se vestidos originalmente, carregando garboso estandarte, dançando e brincando a valer. [...]

As 9 horas da noite fez sua aparição o grupo Triunfo dos Cucumbis. Em frente às redações abriram alas, achando-se no centro do grupo o rei e a rainha, com os seus respectivos cetros, dançaram acompanhando as danças de cantos. (grifos meus)

Se, até o momento, não poderia ter ficado claro para mim, "leitor estrangeiro", a ligação às referências africanas nos Cucumbis (apesar da obviedade contida no seu próprio nome), ao ler esse exemplar do Jornal 
do Comércio uma nova realidade se descortina. Pela primeira vez, é nítida e explícita a alusão à África que a passagem dos Cucumbis causava na imprensa. Para o jornalista, aqueles homens e mulheres estavam vestidos "como nos países africanos", dançavam e cantavam "à moda africana", utilizavam instrumentos "originais", eram liderados por uma Rainha e um Rei, com manto e cetro. Além desses elementos, o próprio nome de um dos grupos é bastante conclusivo: Cucumbis Africanos, que cantam o tema "A África sempre foi livre".

O ano de 1888 é bastante significativo no que se refere à atenção dispensada pela imprensa aos Cucumbis (que ainda é ínfima se compararmos com toda a cobertura dedicada aos préstitos das grandes sociedades carnavalescas). Além dos seis grupos e do texto presente no Jornal do Comércio, encontramos, na Gazeta de Notícias, o texto de Mello Moraes Filho chamado "O Carnaval - Os Cucumbis" e referência aos grupos Triunfo dos Cucumbis, Lanceiros Cucumbis, grupo dos Africanos (descrito como um Cucumbi) e Cucumbis Carnavalescos.

O texto de Mello Moraes pode funcionar como um termômetro para a efervescência de Cucumbis Carnavalescos que vinham conquistando espaço no Rio de Janeiro, pelo menos a partir de 1884. O autor, que à época já despontava como importante conhecedor da cultura popular brasileira, assina o artigo sobre os Cucumbis em fevereiro de 1888, entretanto esse artigo não é publicado na primeira edição de sua obra "Festas e tradições populares do Brasil" que saiu pela Garnier no mesmo ano com o título "Festas populares do Brasil", mas estaria presente nas edições seguintes, publicadas a partir de 1901. Esse indício aponta para a urgência da confecção daquele texto.

Após travar contato com os textos desse ano, o leitor estrangeiro é capaz de entender quão nítida era a matriz africana nesse festejo. Poderia perceber que se tratava de um grupo de descendentes dos africanos escravizados trazidos para o Brasil e que mantinham essa prática, apesar das transformações do tempo.

Outra constatação é a de que, se, em 1884, aparece uma única referência aos Cucumbis, ano a ano esse número se eleva, atingindo seis grupos diferentes nomeados Cucumbi (Tabela 1). Além disso, com o passar do tempo, os jornais se vêm impingidos a esclarecer ao seu pú- 
Tabela 1 - Recorrência de Cucumbis nos jornais Rio de Janeiro, 1884-1888

\begin{tabular}{|c|c|c|c|c|}
\hline Jornal & 1884 & \multicolumn{2}{|c|}{1885} & 1886 \\
\hline \multirow[t]{3}{*}{ Jornal do Comércio } & Quicumbi (caboclos) & \multicolumn{2}{|l|}{ Cacumbis } & Cacumbi Carnavalesco \\
\hline & & \multicolumn{2}{|c|}{ Grupo dos Cacumbis } & Triunfo dos Cucumbis \\
\hline & & \multicolumn{2}{|c|}{ Triunfo dos Cacumbis } & Os Cacumbys \\
\hline \multirow[t]{2}{*}{ Gazeta de Notícias } & --- & \multicolumn{2}{|c|}{ Club Cucumbi } & Cucumbis Carnavalescos (texto) \\
\hline & & \multicolumn{2}{|l|}{ Cucumbis } & Triunfo dos Cucumbis \\
\hline \multirow[t]{2}{*}{ Gazeta da Tarde } & \multirow[t]{2}{*}{---} & \multirow{2}{*}{\multicolumn{2}{|c|}{$-\cdots$}} & Triunfo dos Cucumbis \\
\hline & & & & Os Cacumbis \\
\hline Jornal & \multicolumn{2}{|l|}{1887} & & 1888 \\
\hline \multirow[t]{7}{*}{ Jornal do Comércio } & \multicolumn{2}{|l|}{ Cucumbis Carnavalescos } & \multicolumn{2}{|c|}{ Lanceiros Cucumbis } \\
\hline & \multicolumn{2}{|l|}{ Iniciadores dos Cucumbis } & \multicolumn{2}{|c|}{ Triunfo dos Cucumbis } \\
\hline & \multicolumn{2}{|c|}{ Filha dos Iniciadores dos Cucumbis } & \multicolumn{2}{|c|}{ Cucumbis Carnavalescos } \\
\hline & \multicolumn{2}{|l|}{ Triunfo dos Cucumbis } & \multicolumn{2}{|c|}{ Iniciadora Cucumbis Carnavalescos } \\
\hline & \multicolumn{2}{|l|}{ Cocumbis } & \multicolumn{2}{|c|}{ Filha da Iniciadora Cucumbis Carnavalescos } \\
\hline & & & \multicolumn{2}{|c|}{ Cucumbis Africanos (texto) } \\
\hline & & & \multicolumn{2}{|c|}{ União Lanceiros Cucumbis } \\
\hline \multirow[t]{5}{*}{ Gazeta de Notícias } & \multicolumn{2}{|l|}{ Cucumbis Carnavalescos } & \multicolumn{2}{|c|}{ Lanceiros Cucumbis } \\
\hline & \multicolumn{2}{|l|}{ Iniciadores dos Cucumbis } & \multicolumn{2}{|c|}{ Triunfo dos Cucumbis } \\
\hline & \multicolumn{2}{|c|}{ Filha dos Iniciadores dos Cucumbis } & \multicolumn{2}{|c|}{ Cucumbis Carnavalescos (texto) } \\
\hline & \multicolumn{2}{|c|}{ Triunfo dos Cucumbis (texto) } & \multicolumn{2}{|c|}{ Cucumbis (texto Mello Moraes) } \\
\hline & Cucumbis (texto) & & Cucumbi & Africanos (texto) \\
\hline Gazeta da Tarde & Cucumbis & & Sociedad & Iniciadora Cucumbis Carnavalescos \\
\hline & & & Iniciador & Cucumbi Carnavalesco \\
\hline & & & União La & ceiros de Cucumbis \\
\hline & & & Triunfo d & s Cucumbis \\
\hline
\end{tabular}

300 Afro-Ásia, 49 (2014), 273-312 
blico geral o que eram aqueles grupos. Assim, temos dois textos sobre os Cucumbis em 1886, dois em 1887 e quatro em 1888, sendo um deles o artigo de Mello Moraes Filho que temos analisado ao longo do capítulo.

Entretanto, como não sou um leitor estrangeiro do século XIX, mas sim um historiador, preciso empreender uma análise mais complexa dessas conclusões gerais extraídas quase literalmente dos jornais. Acredito ser possível visualizar, na experiência dos Cucumbis Carnavalescos da década de 1880, elementos da construção de identidades (baseadas em imagens da África) e de um processo de crioulização dessa prática. Ambos os processos dialogaram constantemente, não sem conflitos e negociações, com a luta em torno do conceito de liberdade, intensamente desenvolvido na cidade do Rio de Janeiro.

\section{"Pretos à moda da África": identidades africanas e visões da liberdade}

A África, um continente imenso e complexo, deve ser sempre pensada de forma plural e polifônica. Esse cuidado vem sendo tomado pelos estudiosos que se debruçam sobre suas histórias e sociedades há algumas décadas. A um oceano de distância, aqui no Brasil, esse mesmo cuidado deve ser tomado quando olharmos para as inúmeras imagens de "áfricas" criadas, desde que os primeiros africanos escravizados foram trazidos para cá. Tais "áfricas" foram tão variadas quanto os povos escravizados e as diversas conjunturas sociais e culturais com as quais se defrontaram. Essas construções sofreram com a ação do tempo e do espaço e, por isso, precisam ser entendidas dentro de seu contexto, considerando-se as relações e os diálogos existentes com os contemporâneos - outros escravos, crioulos ou africanos, libertos, livres, autoridades, imprensa.

Quando um grupo de pessoas socialmente reconhecidas como negras se reúne, se organiza, investe tempo e economias para dar vida a um grupo que comporta inúmeras referências de um passado africano, com o objetivo de desfilar nas ruas do Rio de Janeiro em plena década de 1880, durante a festa mais concorrida e disputada da cidade, essas pessoas desejam expressar alguma coisa. A presença dos Cucumbis Carnavalescos não deve ser compreendida, como muitos jornalistas coevos fizeram, 
como apenas manifestação do exótico, da inocência de uma "raça afetiva por excelência", que estaria fadada ao desaparecimento. ${ }^{44}$ Precisamos ir além dessa interpretação simplista (que acabou sendo compartilhada por muitos pensadores que entenderam experiências similares como meras sobrevivências do passado).

Como nos alertou Wlamyra Albuquerque, em sua inspirada análise sobre a construção de imagens de "áfricas" em carnavais baianos de finais do século XIX e início do XX, não devemos cair na dicotomia analítica que estabelece dois únicos polos possíveis para atuação de grupos negros na sociedade escravista: de um lado, estaria a opção da integração social por critérios brancos, em outras palavras, a assimilação; de outro lado, a resistência, como, por exemplo, a empreendida pelos batuques africanos, avessos à integração e assimilação. Para Albuquerque, essa dicotomia deve ser evitada e devemos nos preocupar mais em "pensar sobre como o passado africano estava compondo a experiência daqueles que lidavam com os estigmas do escravismo e os limites da cidadania negra". Devemos mover nossa "curiosidade da assimilação/resistência para as mensagens cifradas que, oportunamente, eram traduzidas no interior da própria comunidade da gente de cor". ${ }^{45}$

Essas reflexões são produzidas pela autora quando analisa especificamente dois grupos carnavalescos baianos que desfilaram naqueles carnavais: Pândegos d'África e Embaixada Africana. Seus questionamentos serviram de inspiração para minha análise. Os contextos são diferentes e os grupos também, mas acredito ser possível visualizar um movimento semelhante ao descrito por Albuquerque para os grupos baianos e a ação dos Cucumbis Carnavalescos no Rio de Janeiro.

Faço minhas as indagações da autora quando se pergunta "quais os sentidos políticos e culturais subjacentes às representações de reis e reinos africanos nos préstitos dos clubes negros?". Tal pergunta se torna ainda mais intrigante quando transposta para o contexto do carnaval carioca da década de 1880, auge do movimento abolicionista e de debates acerca do lugar dos libertos e negros livres na sociedade que se construiria

\footnotetext{
44 Moraes Filho, Festas e tradições.

45 Albuquerque, O jogo da dissimulação, p. 200.
} 
pós-abolição. Albuquerque pergunta também "que leituras da África a imagem do poderoso rei etíope suscitava na plateia predominantemente negra?". ${ }^{46}$ Para os Cucumbis, a questão é: qual o impacto do Rei do Congo e sua Rainha para a plateia que, em grande parte, descendia de africanos escravizados na região da África Centro-Ocidental, onde a simbologia do reino do Congo era muito poderosa?

Até o momento, a análise mais detalhada do carnaval carioca (e também dos Cucumbis) entre as décadas de 1890 e 1920 foi empreendida por Maria Clementina Pereira Cunha em seu Ecos da folia.$^{47}$ Entretanto, apesar das fundamentais contribuições da autora para uma história social do carnaval carioca, sua análise não contempla uma tentativa de se aproximar das referências africanas contidas nos versos dos Cucumbis.

Em plena década de 1880, os Cucumbis Carnavalescos utilizam a festa como lugar de memória, onde recontam histórias da África e reforçam uma identidade. Seguindo os passos trilhados por Robert Slenes em sua análise de versos de jongos do Sudeste, pretendo buscar, nas palavras cantadas pelos membros dos Cucumbis Carnavalescos (registradas por Mello Moraes), os múltiplos significados possíveis para seus participantes. Seus versos podem trazer novas possibilidades de entendimento dos Cucumbis Carnavalescos da década de 1880.

O Rei canta, ao dançar na abertura do préstito: "Sou Rei do Congo / Quero brincar / Cheguei agora / De Portugal". ${ }^{48}$ A referência ao reino do Congo é explícita. O rei dessa festa poderia representar simbolicamente todos os reis do Reino do Congo, que se localizava no norte da atual Angola, unificado no século XVI. Mas também poderia aludir ao Rei Baltasar, um dos três reis magos, cuja festa acontecia em 6 de janeiro, data em que as congadas também se realizavam. Segundo Mariza Soares, na igreja da Lampadosa "o rei Baltazar [era] homenageado como rei do Congo" na segunda metade do século XVIII. ${ }^{49}$

A menção a Portugal pode ser explicada pelas estreitas relações do reino do Congo com a coroa portuguesa nos primeiros anos de contato. A

\footnotetext{
46 Albuquerque, O jogo da dissimulação, pp. 208-210.

47 Cunha, Ecos da folia.

48 Versos recolhidos por Moraes Filho, Festas e tradições.

49 Soares, Devotos da cor, p. 156.
} 
aristocracia congolesa desde muito cedo penetrou a sociedade lusitana, valendo-se da conversão ao cristianismo e estabelecendo redes comerciais e alianças matrimoniais. Muitos nobres congoleses se transferiram para Portugal para estudar e estreitar laços políticos e econômicos. ${ }^{50}$

O verso cantado pelo Capataz em direção ao Rei abre novas possibilidades: "Quenguerê, oia congo do má / Gira Calunga, / Manú quem vem lá".

Segundo Mary Karash, quenguelê é uma entidade espiritual da sétima falange da linha de Xangô. ${ }^{51}$ Nei Lopes completa, afirmando que, na umbanda, quenguele é uma entidade-guia, chefe da falange dos Pretos Velhos, na linha de Xangô, e é palavra "provavelmente [derivada] do Lingala kengele, 'tomar conta, zelar'. Em quioco, o vocábulo kengele exprime a ideia de 'aparecer, mostrar-se; deixar-se ver, mas sem se aproximar'". ${ }^{52}$ Pierre Verger, analisando os orixás do candomblé da Bahia, afirma que o

[...] arquétipo de Xangô é aquele das pessoas [...] altivas e conscientes de sua importância real ou suposta [...] que possuem um elevado sentido da sua própria dignidade e das suas obrigações [...] com profundo sentimento de justiça. ${ }^{53}$

Altivez, consciência de sua importância, dignidade e obrigações e com profundo sentimento de justiça. Essas são as principais características do arquétipo de Xangô descrito por Verger. É sintomático que a entidade Quenguelê esteja, na umbanda, atualmente afiliada à linha de Xangô e que, nos versos dos Cucumbis, seja associada aos reis do Congo. Estariam essas características presentes também em Quenguelê e, por isso, favoreceram a aproximação dessa entidade com Xangô? Os limites desse estudo não nos permitem responder, entretanto essa suposição me parece bastante verossímil e reforça a imagem do rei do Congo, nobre, importante e justo, sendo representado no carnaval.

No segundo verso da estrofe surge a palavra Calunga que, de

\footnotetext{
50 Elikia M'Bokolo, África negra: história e civilizações, tomo 1 (até o século XVIII). Salvador: Edufba; São Paulo: Casa das Áfricas, 2009. pp. 413-15.

Karash, $A$ vida dos escravos.

52 Nei Lopes, Novo dicionário banto do Brasil, Rio de Janeiro: Pallas, 2003, p. 181.

53 Pierre Verger, Orixás: deuses iorubás na África e no Novo Mundo, Salvador: Corrupio, 2002.
} 
acordo com Nei Lopes, tem origem no termo multilinguístico banto Kalunga, que encerra ideia de grandeza, imensidão, designando Deus, o mar, a morte. Na umbanda, calunga-grande significa o mar, o oceano, enquanto calunga-pequeno, cemitério. ${ }^{54}$ Wyatt McGaffey, afirma que, no Congo atual, as "atividades de culto estão centradas nas duas principais rotas de comunicação entre os mundos, que são a água e o túmulo". 55

Calunga, nas palavras de Robert Slenes, significava também a linha divisória que separava o mundo dos vivos do mundo dos mortos. Portanto, "atravessar a kalunga (simbolicamente representada pelas águas do rio ou do mar [...]) significava 'morrer', se a pessoa vinha da vida, ou 'renascer', se o movimento fosse no outro sentido". ${ }^{56}$ Esse sentido era compartilhado por grande parte dos povos da região Congo-Angola, assim como a caracterização da cor branca como cor dos mortos e espíritos, em oposição ao preto, cor dos homens. Assim, como afirma Slenes, ficou fácil para os povos bantos associarem a terra dos brancos com o mundo dos mortos, e a travessia do Atlântico como uma dolorosa transposição da Calunga.

Após a apresentação do rei e da rainha, o Mameto entra em cena dançando e centralizando o préstito em torno de si. Entretanto, não tarda em ser assassinado por um Caboclo, momento em que é evocado um dos personagens mais interessantes da trama: o Quimboto, o feiticeiro africano.

O Quimboto aparece em meados do cortejo e ocupa um papel crucial: the é impingida a missão de reviver o Mameto, filho do casal real, sob pena de morte, caso falhe em seu intento. Mas suas recompensas também serão valiosas se sua magia for capaz de vencer a morte. As descrições do personagem afirmam que ele traz, enrolada no pescoço, uma cobra viva. A presença desse réptil não é por acaso. Segundo Robert Slenes, a cobra era um símbolo poderoso e difundido na África Centro-Ocidental; entre os congos, por sua capacidade de mudar de pele sem passar para o Outro Mundo, era associada ao imperecível. ${ }^{57}$

54 Lopes, Novo dicionário, pp. 57-8.

55 Wyatt McGaffey, "The West in Congolese Experience", in Philip D. Curtin (ed.), Africa and the West (Madison: The University of Wisconsin Press, 1972), pp. 51-6.

56 Robert Slenes, "Malungo n'goma vem! África coberta e descoberta do Brasil”, Revista USP, n. 12 (1991-1992), p. 53.

57 Slenes, "Malungo n'goma vem", p. 134. 
E parece mesmo que a religiosidade dos povos da África Centro-Ocidental teve papel de destaque nos Cucumbis de finais do século XIX. Segundo Mary Karash, ao longo da primeira metade do século XIX, a religiosidade dos escravos e negros livres do Rio de Janeiro tem como elementos centrais a tradição religiosa da vasta região cultural do centro-oeste africano. O que seria reforçado, afirma a autora, pelo predomínio numérico de pessoas escravizadas nessa região que aportaram no Rio nesse período, pela atual semelhança da umbanda carioca com as religiões curativas de Angola e, sobretudo, pelo próprio caráter "aberto" dessas tradições, que não se prendiam a um "conservadorismo" religioso. ${ }^{58}$

Os feiticeiros eram muito comuns no Rio de Janeiro até bem avançado o século XIX. Hábeis manipuladores de drogas e venenos, eram líderes religiosos poderosos e eficazes desde o período colonial. Seus amuletos de proteção estavam presentes por toda a cidade; chifres contra mau-olhado, cavalo-marinho para expulsar os demônios, e tantos outros patois eram vendidos pelas ruas da cidade.

O Quimboto também trazia seus amuletos pelo corpo (cadeias de ferro, cobras e víboras, peles de répteis secas, búzios, raízes e resinas) para contornar qualquer desventura e trazer o bem de volta à ordem natural do universo. No Cucumbi, seu desafio é talvez grande demais. Ele precisa vencer a maior das desventuras: a morte. A força de sua magia é testada contra a força do Caboclo brasileiro que mata o Mameto.

Dançando em torno do corpo juvenil do filho da rainha, o feiticeiro canta: "Zumbi, Zumbi, oia Zumbi! / Oia Mamêto muchicongo. / Oia papêto".

Segundo Câmara Cascudo, a palavra Zumbi tem origem na região de Angola e é usada no Brasil em várias localidades e ainda com os

\footnotetext{
58 Slenes, "Malungo n'goma vem”, p. 134. Segundo Karash, a religiosidade dos povos da África Centro-Ocidental consegue prevalecer sobre o catolicismo, o islamismo e o candomblé justamente por estar aberta ao novo, buscando um "rearranjo" de rituais, símbolos e crenças, buscando preservar o complexo ventura/desventura, noção central da cosmologia banto. Segundo essa visão de universo, o bem tende a prevalecer na ordem natural, enquanto o mal é sempre causado por espíritos malévolos e sentimentos malignos. É preciso que especialistas interfiram para que o bem prevaleça sobre o mal. Com o intuito de manter a ventura sobre a desventura, os povos que compartilham essa tradição religiosa abrem espaço para novas práticas e são muito mais flexíveis ao novo. Karash, $A$ vida dos escravos.
} 
mais variados sentidos. Citando Beaurepaire-Rohan (1889), Cascudo afirma que Zumbi seria um "ente fantástico que [...] vagueia no interior das casas em horas mortas [e etimologicamente] é vocábulo da língua bunda, significando duende, alma do outro mundo". ${ }^{59}$ Citando Vale Cabral, afirma que zumbi significa, entre os angolanos, "gente que morreu, alma do outro mundo [..] Na tradição oral de muitas nações africanas, fantasma, Diabo, que anda de noite pelas ruas". No Haiti, prossegue Cascudo, há os Zombies, “cadáveres animados por força mágica, sob a vigilância constante do feiticeiro". Conclui com outra citação, de Óscar Ribas, que nos é útil: "Zumbi é a alma de pessoa falecida recentemente, num período não secular", segundo o qual zumbi deriva de kuzumbika, que significa "perseguir a mando de um feiticeiro".

É significativo que o feiticeiro evoque Zumbi, no processo de encantamento que busca trazer à vida novamente o Mameto. Trata o recém-falecido como Zumbi, ou seja, alma do outro mundo, mas que, afligida pelos feitiços corretos, pode retornar sob o comando do Quimboto.

A ressurreição do Mameto demonstra a força e o conhecimento mágico e sobrenatural do feiticeiro africano. Por meio de música, dança, ${ }^{60}$ utilização de amuletos e evocando as entidades corretas, ele consegue derrotar a morte causada pelas forças do Caboclo, provável representante das forças ameríndias e/ou brasileiras, como sugeriu Mary Karash. ${ }^{61}$

A vitória do feiticeiro e o restabelecimento da ventura sobre a desventura encaminham o préstito para o seu desfecho. $\mathrm{O}$ feiticeiro evoca São Benedito como santo maior encarregado de fechar o desfile. Esse santo, negro, nascido na Etiópia no século XVI, era um dos mais populares entre escravos, libertos e negros livres do Rio de Janeiro.

Portanto, a presença de nexos culturais com a região Congo-Angola foi muito relevante na constituição dos Cucumbis. A imagem da África estava centralizada nas tradições bantos e pôde ser mais facilmente

59 Luiz da Câmara Cascudo, Made in África, Rio de Janeiro: Civilização Brasileira, 1965, p. 114. As citações seguintes são dessa mesma obra, pp. 114-8.

${ }^{60}$ Karash, A vida dos escravos, p. 361. "Dança, música e transe estão no âmago do ritual centro-africano: 'a música cura, a música comunica-se com os de cima e de baixo do mundo visível; ela é inspirada' [Craemer]".

${ }^{61}$ Essa ideia da vitória da feitiçaria africana sobre as forças americanas, representada pela ressurreição do Mameto, é defendida por Karash, A vida dos escravos, p. 357. 
entendida entre os descendentes de africanos no Rio de Janeiro. Uma identidade cultural que era anualmente reelaborada em seus préstitos carnavalescos, numa performance que valorizava as memórias da África e da escravidão.

Essa experiência dos Cucumbis assim como sua representação nos jornais, nos dias de carnaval, a partir de 1884, deve ser entendida dentro do contexto político, social e cultural da Corte naquele período. O Rio de Janeiro vivia um momento de ebulição social com a crescente força do movimento abolicionista e a constante desautorização de senhores de escravos, explicitados por fugas, pelo número cada vez maior de escravos vivendo sobre si e pelo vertiginoso aumento do número de alforrias (condicionais ou não). ${ }^{62}$ Ao longo da década de 1880, em consonância com os abolicionismos urbanos, os escravos enfraqueciam a autoridade senhorial com suas revoltas, fugas coletivas para os quilombos abolicionistas, denúncias de maus tratos e manifestações públicas em prol do fim da escravidão. A abolição tornava-se uma bandeira popular. ${ }^{63}$

Defendo que a presença cada vez mais impactante dos Cucumbis Carnavalescos a partir do ano de 1884 está diretamente relacionada com essa nova cultura política de liberdade, que vinha sendo construída no Rio de Janeiro a partir de diversas frentes (abolicionismo parlamentar, imprensa, participação popular, seja de escravos ou livres) e que tinha no carnaval um vetor de criação, transformação e representação.

O carnaval foi a festa escolhida pela população carioca para expor seu desejo de liberdade e, no caso dos Cucumbis Carnavalescos, também seu desejo de mostrar e criar uma identidade própria. Seus membros elaboraram uma imagem de cortejo carnavalesco saindo juntamente com as demais sociedades e, apesar de usar muitos dos seus expedientes (como por exemplo, passar pela Rua do Ouvidor, parar diante das

\footnotetext{
62 Sidney Chalhoub, Visões da liberdade: uma história das últimas décadas da escravidão na Corte, São Paulo: Companhia das Letras, 1990.

${ }^{63}$ Eric Brasil Nepomuceno e Camila Mendonça, "1888: Abolição e abolicionismos”, in Carolina Vianna Dantas, Hebe Mattos e Martha Abreu (orgs.), O negro no Brasil: trajetórias e lutas em dez aulas de história (Rio de Janeiro: Objetiva, 2012), pp. 73-84; Eduardo Silva, "Domingo, dia 13: o underground abolicionista, a tecnologia de ponta e a conquista da liberdade", in Martha Abreu e Matheus Serva Pereira (orgs.), Caminhos da liberdade: histórias da abolição e do pós-abolição no Brasil (Niterói: PPGHISTÓRIA-UFF, 2011), pp. 29-37.
} 
redações dos jornais), mantiveram diferenças significativas em relação aos demais grupos. Eles traziam às ruas uma África simbolicamente positivada, com seu rei e rainha, príncipes e princesas, além de banda, guarda, feiticeiros e súditos.

Ao representar imagens da África, os Cucumbis estabeleciam critérios de pertencimento e identificação com certos grupos e excluíam outros. $\mathrm{O}$ rei do Cucumbi era congo, seus personagens tinham nomes africanos e quem se sagrava vencedor ao final do cortejo era justamente o reino africano. Essa imagem da África positivada que se faz presente no carnaval dos Cucumbis foi criada a partir de um rico arcabouço cultural presente no Rio de Janeiro, cujos elementos tentei apresentar anteriormente. ${ }^{64}$

Ao longo de todo o século XIX, as gentes de cor da cidade travaram contato com tradições africanas de múltiplas origens e, dentre elas, houve uma significativa predominância banto. Os Cucumbis descritos por memorialistas, folcloristas e viajantes foram sempre associados a elementos desses povos da África Centro-Ocidental.

Portanto, os membros dos Cucumbis Carnavalescos trouxeram para o carnaval carioca uma expressão cultural baseada na fusão e transformação de inúmeras referências africanas e as carnavalizam positivamente. Essa África negra e positiva disputa espaços com as grandes sociedades carnavalescas e outros grupos populares que tentavam se inspirar no modelo europeu de carnaval. É importante ressaltar que esses foliões dos Cucumbis poderiam ter escolhido outras formas de sair às ruas, entretanto, preferiram deliberadamente trazer às ruas uma manifestação que seria prontamente associada ao passado africano tanto pelas autoridades e pela imprensa quanto por seus iguais. Celebravam, dessa maneira, a força de toda uma complexa trama de símbolos e tradições ligadas a um passado africano, reelaborado a partir dos contatos com as sucessivas gerações crioulas e com as transformações sociais cariocas.

\footnotetext{
${ }^{64}$ Outros grupos da década de 1880 apresentavam nomes com referências explícitas à África. Nação Angola, Dança Benguela, Cabindas, Cabundás aparecem mais de uma vez nos jornais do período. Infelizmente, não foi possível recolher mais informações sobre eles além de seus nomes, contudo, sua presença já demonstra que o carnaval era um espaço requisitado pela população de cor para expressar suas concepções de festa e tradição; também não encontrei os registros policiais para o período imperial sobre as licenças obtidas por essas sociedades e pelos Cucumbis.
} 
Esses homens e mulheres negros pretendiam aparecer no carnaval como indivíduos que compartilhavam uma mesma identidade baseada em práticas africanas. Contudo, majoritariamente, eles não eram africanos. A grande maioria dos participantes do carnaval eram jovens de menos de 30 anos (pelo menos aqueles que eram presos e registrados na Casa de Detenção). ${ }^{65}$ Eram, sim, crioulos, se escravos, ou eram libertos e negros livres brasileiros, filhos e netos de africanos escravizados que, a partir da herança cultural de seus antepassados, criaram no carnaval carioca uma forma crioula de brincar.

É o próprio Mello Moraes quem afirma: “como é natural, a tradição africana acha-se corrompida pelas gerações crioulas, mas não a ponto de desconhecer-se o que há de primitivo como os costumes autênticos" ${ }^{66}$ Vou mais longe na afirmativa: os Cucumbis Carnavalescos são uma expressão de forma crioula de cultura. Crioula, no sentido de que a prática do Cucumbi Carnavalesco surgiu como algo novo a partir dos confrontos da experiência da escravidão e das novas realidades sociais do Rio de Janeiro na crise do escravismo. Crioula, pois, não é nem africana (mesmo tendo tantos elementos desse passado) nem ibérica (apesar das referências aos reisados e irmandades católicas). O Cucumbi Carnavalesco é crioulo por representar uma elaboração cultural nova, com base em referências profundas do passado escravista e africano, mas responder às novas realidades culturais e sociais.

Mello Moraes Filho disse, na última frase de seu artigo da Gazeta de Notícias: "é bem que os crioulos perpetuem no Brasil esses costumes, com que seus pais adoçavam o fel do exílio e encantavam as noites, sem aurora, da escravidão!". Esses crioulos transformaram os costumes de seus "pais" em diálogo com as transformações culturais e sociais do Rio. Por meio da prática nova que criaram, mesmo mantendo o nome antigo, conquistaram espaço para expressar uma identidade e demonstrar publicamente suas tradições e inovações.

Apesar do olhar preconceituoso e muitas vezes racista que despertaram, os Cucumbis Carnavalescos são um ótimo exemplo de atuação

\footnotetext{
${ }_{65}$ Nepomuceno, "Carnavais da abolição".

${ }^{66}$ Moraes Filho, Festas e tradições.

310 Afro-Ásia, 49 (2014), 273-312
} 
positiva e coletiva de indivíduos negros na crise do escravismo. Não negaram sua ascendência africana e conquistaram o direito à liberdade de ser atores criativos da festa carnavalesca, valendo-se do momento propício, oriundo da popularização do abolicionismo. ${ }^{67}$

Porém, a presença dos Cucumbis Carnavalescos nos jornais e, aparentemente, nas ruas do Rio de Janeiro, não resistiram às transformações sociais e culturais após a abolição da escravidão e da proclamação da república. Os relatos nos jornais se tornam cada vez mais escassos até desaparecerem ainda na década de $1890 .{ }^{68} \mathrm{Nas}$ fontes policiais, entre 1889 e 1914, não pude encontrar nenhum pedido de licença de grupo intitulado Cucumbi. ${ }^{69}$ Segundo Cunha, seus "africanismos" tão fortes e evidentes teriam impossibilitado que continuassem a ter destaque durante a república: sem o abolicionismo, seriam relegados ao esquecimento e tratados como desordeiros. ${ }^{70}$ Seus membros e muitas de suas práticas seriam incorporados aos ranchos e cordões da cidade. Sobre esses processos de transformações ainda há muito que se estudar, entretanto, tais objetivos extrapolam os limites deste artigo, que já se encontra em sua quarta-feira de cinzas.

67 Silva, "Domingo, dia 13".

68 As últimas aparições dos Cucumbis nos jornais remontam a 1893. Cunha, Ecos da folia.

${ }^{69}$ A documentação encontra-se no Arquivo Nacional - GIFI - Documentos de polícia: 6C50, 6C63, 6C135, 6C170, 6C171, 6C213, 6C250, 6C251, 6C $364,6 \mathrm{C} 365,6 \mathrm{C} 367,6 \mathrm{C} 368,6 \mathrm{C} 377,6 \mathrm{C} 378$, 6C432, 6C433, 6C464, 6C465, 6C479, 6C480, 6C530 e corresponde a anos intermitentes entre 1898 e 1918

70 Cunha, Ecos da folia. 


\title{
Resumo
}

Este artigo apresenta uma pesquisa sobre os Cucumbis Carnavalescos. Esses grupos alcançaram a sua maior notoriedade na segunda metade da década de 1880, aparecendo cada vez mais nos jornais e conquistando seu espaço nas ruas durante os dias de carnaval. Eles foram reconhecidos, por jornalistas e outros observadores contemporâneos, como "africanos" — "danças africanas", "instrumentos africanos" e "trajes africanos" — desfilando pelas ruas da cidade. O objetivo principal deste trabalho é tentar entender os possíveis significados por trás do ato de criar, preservar e transformar uma ação festiva que tem o passado africano como elemento fundamental para a formação de identidade para os seus membros. Essa identidade africana foi reforçada precisamente enquanto a luta pela abolição da escravatura tornou-se mais intensa e os debates sobre cidadania tornaram-se mais fortes do que nunca.

Palavras-chave: Carnaval - Cucumbi - abolição da escravidão - Rio de Janeiro

\begin{abstract}
This paper presents research about the carnival Cucumbis. These groups had reached their greatest notoriety in the second half of the 1880s, appearing more and more in the newspapers and conquering their space in the streets during the days of carnival. They were recognized as "Africans" by the journalists and other contemporaneous observers: with their "African dances", "African instruments", and "African costumes" parading through the streets. The main objective here is to try to understand the possible meanings behind the act of creating, preserving, and changing one festive action that has the African past as an essential element to the making of identity for their members. This African identity was strengthened precisely while the struggle for the abolition of slavery grew more intense and the debates about citizenship had become stronger than ever.
\end{abstract}

Keywords: Carnival - Cucumbi - abolition of slavery - Rio de Janeiro 